Journal of

Literary Education

\title{
Engaging the Social Imagination in the College Classroom Through Radiant Readings of Global Picturebooks
}

\author{
Activar la imaginación social en el aula universitaria a través de lecturas \\ radiantes de álbumes globales
}

\author{
Activar la imaginació social a l'aula universitària a través de lectures \\ radiants d'àlbums globals
}

\author{
Petros Panaou. University of Georgia, USA. ppanaou@uga.edu \\ https://orcid.org/0000-0001-9265-9942
}

\begin{abstract}
Building on Kelly Wissman's (2019) work, the article describes and analyzes artifacts from the author's college children's literature class, during which students read radiantly: in ways that may take them outside of themselves, their realities, and points of view, "like rays emitting from the sun, to seek out alternative perspectives, new directions, and unique pathways" (p. 16). The analysis of these collected student artifacts is guided by Wissman's understanding of the social imagination as the capacity of a reader to imagine "the thoughts, feelings, and experiences of others" as well as "to invent visions of what should be and what might be" (p. 15). It also builds on the theoretical framework developed by Kathy Short (2019) in relation to the social responsibility that needs to be practiced and cultivated by those involved in the creating, teaching, and reading of global children's literature. Nurturing reading as an act of creativity and fostering dialogic inquiry around global picturebooks is shown to be quite effective in engaging college students' social imagination. The author brings evidence from the prompts and artifacts that supports this effectiveness, demonstrating the different ways in which students were able to read Two White Rabbits (2015) and The Arrival (2007) radiantly. The prompts were successful mainly because, by design, they required readers to use their imagination and creativity as well as pay close attention to the picturebooks' visual aesthetics in order to fill in the gaps. Another important reason behind the students' radiant readings was the selection of these specific picturebooks, which fit Jessica Whitelaw's (2017) definition of disquieting picturebooks as they encourage their readers to embrace unfamiliarity and discomfort.
\end{abstract}

Keywords: global picturebooks, college classroom, reading radiantly, social imagination, social responsibility, disquieting picturebooks 


\section{Resum}

Tot basant-se en el treball de Kelly Wissman's (2019), l'article descriu i analitza instruments de les classes sobre literatura infantil que imparteix l'autor a la universitat, en la qual l'alumnat havia de read radiantly (llegir radiantment): de manera que els traga de si mateixos, de les seues realitats i dels seus punts de vista "com rajos emesos pel sol, eixir a la cerca de perspectives alternatives, noves direccions i sendes singulars” (p.16). L'anàlisi d'aquests instruments acumulats de l'alumnat es guia per la forma d'entendre la imaginació social com la capacitat de la persona lectora d'imaginar "els pensaments, sentiments i experiències d'altri" al mateix temps que "inventa imatges del que hauria de ser i el que podria ser" (p.15). També es construeix sobre el marc teòric desenvolupat per Kathy Short (2019) amb relació a la responsabilitat social que ha de practicar-se i conrear-se per les persones involucrades en la creació, ensenyament i lectura de la literatura infantil a nivell global. Promoure la lectura com a un acte de creativitat i fomentar una conversa dialògica sobre àlbums il·lustrats a nivell global es demostra com una forma efectiva d'involucrar la imaginació social de l'alumnat universitari. L'autor presenta evidència de les premisses i instruments que demostren aquesta efectivitat, tot il·lustrant diferents formes en la quals l'estudiantat va ser capaç de llegir radiantment Two white rabbits (Dos conills blancs) i The arrival (L'arribada) (2007). Una de les raons principals de l'èxit va ser que, per disseny, les premisses de les quals es partia requerien que els lectors i les lectores feren servir la seua imaginació i creativitat al mateix temps que paraven atenció a la càrrega estètica i visual dels àlbums il·lustrats per omplir els forats. Una altra raó important per l'acollida d'una lectura radiant de l'alumnat va ser la selecció d'aquests àlbums il-lustrats que segueixen la definició proposada per Jessica Whitelaw (2017) de disquieting picturebooks (àlbums il·lustrats inquietants) ja que incentiven als lectors a acceptar el desconeixement i la incomoditat.

Paraules clau: àlbums il·lustrats globals, lectura radiant, imaginació social, responsabilitat social, àlbums il.lustrats inquietants

\section{Resumen}

Basándose en el trabajo de Kelly Wissman's (2019), el artículo describe y analiza instrumentos de las clases sobre literatura infantil que imparte el autor en la universidad, en la que los alumnos tenían que read radiantly (leer radiantemente): de forma que les sustraiga de sí mismos, de sus realidades y de sus puntos de vista, "como rayos emitidos por el sol, salir a la búsqueda de perspectivas alternativas, nuevas direcciones y senderos singulares" (p. 16). El análisis de estos instrumentos acumulados del alumnado se guía por la forma de entender la imaginación social como la capacidad de la persona lectora de imaginar "los pensamientos, sentimientos y experiencias de otros" a la vez que "inventa imágenes de lo que debería ser y lo que puede ser" (p.15). También se construye sobre el marco teórico desarrollado por Kathy Short (2019) con relación a la responsabilidad social que debe practicarse y cultivarse por las personas involucradas en la creación, enseñanza y lectura de la literatura infantil a nivel global. Promocionar la lectura como un acto de creatividad y fomentar una conversación dialógica sobre álbumes ilustrados a nivel global se demuestra como una forma efectiva de involucrar la imaginación social del alumnado universitario. El autor presenta evidencia de las premisas e instrumentos que demuestran esta efectividad, ilustrando diferentes formas en que el estudiantado fue capaz de leer radiantemente Dos conejos blancos [edición inglesa Two White rabbits](2015) y The Arrival (Emigrantes) (2007). Una de las razones principales del éxito fue que, por diseño, las premisas de las que se partía requerían que los lectores y las lectoras usaran su imaginación y creatividad a la que vez que prestaban atención a la carga estética y visual de los álbumes ilustrados para rellenar los huecos. Otra razón importante para la acogida de una lectura radiante del alumnado fue la selección de estos álbumes ilustrados, que siguen la definición propuesta por Jessica Whitelaw (2017) de disquieting picturebooks (álbumes ilustrados inquietantes) ya que incentivan a sus lectores a aceptar el desconocimiento y la incomodidad.

Palabras clave: álbumes ilustrados globales, lectura radiante, imaginación social, responsabilidad social, álbumes ilustrados inquietantes 


\section{Story and the Social Imagination}

Kathy Short (2019) points out that our worldviews develop as an everchanging web of interconnected stories and that our human lives themselves are essentially stories (pp. 1-2). This understanding of story allows us to appreciate the potential of global children's literature to encourage the "narrative imagination so that readers enter story worlds to experience how people live, feel, and think around the world" (p. 2). Deborah Ellis (2019), the acclaimed author of global children's literature, further extends this thinking when she says that through literature, we can create the world we want to have and so "stories, especially those for children, are not just about what is but, more importantly, what can be" (p. 9). Patricia Enciso (2017) captures the important social role stories can play when she writes that "stories are central to the work of reimagining past, present, and future relations" (p. 30). Stories can propose alternatives to our habitual and normalized present through the mode of "what if" and "what might be." In this manner, stories help us understand and use our imagination as social practice (Enciso, 2017).

Several scholars attribute the relationship between story and imagination as social practice to stories' ability to energize the reader's social imagination. Kelly Wissman (2019) partly defines the social imagination as "the capacity of a reader to grasp the thoughts, feelings, and experiences of characters and to extrapolate beyond what is presented in the text to imagine the thoughts, feelings, and experiences of others" (p. 15). Additionally, social imagination enables us to imagine different versions of our society and envision social change. In this sense, Wissman espouses philosopher Maxine Greene's (1995) understanding of the social imagination as "the capacity to invent visions of what should be and what might be in our deficient society, on the streets where we live, in our schools" (p. 5). Greene contends that the arts activate the social imagination and invite us to become "wide awake" to the troubles and possibilities within our shared world.

When we view imagination in this manner, we begin to think of it more as a transformative experience rather than a character trait (Enciso, 2017, p. 31). This is why Enciso defines imagination as social practice: "Imagination entails the effort to manage gaps in time between what is, what has been, and what might become within contexts of unequal histories and expectations for speaking and being heard" (p. 35). Her use of the word "effort" implies that readers and storytellers can consciously activate and cultivate their social imagination. 


\section{Reading Global Picturebooks Radiantly}

Writing about the narrative imagination and social responsibility, Short (2019) suggests that socially responsible readers of global literature identify and reflect on the cultural locations and biases they bring to a book, and become aware of how their cultural locations do and do not connect with the cultural location of that book. Most importantly, they are willing to be open and to learn from another's life and experiences (p. 7).

Wissman (2019) also emphasizes a stance of openness when she coins the term radiant reading. This is a way of reading that engages our social imagination by allowing us to go outside of ourselves. In her analysis of "The state of the art in picturebook research from 2010 to 2020" Evelyn Arizpe (2021) identifies Wissman's work as a promising critical literacy approach that enhances readers' active meaning-making through close attention to the aesthetic and material aspects of picturebooks. Arizpe asserts that reading radiantly has been shown to develop students' ability and inclination to address issues of inequality and injustice (p. 269).

According to Wissman (2019), when we read radiantly we are "open to books that may take us outside of ourselves, our own experiences, realities, and points of view" (p. 16). Openness allows the radiant reader to "be inspired, like rays emitting from the sun, to seek out alternative perspectives, new directions, and unique pathways" (p. 16). This outward movement, visualized through the metaphor of sunbeams, permeates the social practice of reading radiantly. Using Wissman's elements of reading radiantly, I have created the graphic in Figure 1, which further visualizes the stance and practice of openness/outward movement performed by the reader.

Each and every ray in figure 1 points to openness; from being open to be moved and transformed, to embracing the imagination as a social guide, to reading in ways that may move us to action. Referring specifically to the reading of picturebook narratives, Wissman (2019) calls for reading experiences that are "charged encounters" with picturebooks, in which the reader "has a deep connection with the book and a heightened awareness of its aesthetic features" (p. 15). During this kind of reading experiences "the text may illuminate a new way of thinking and also inspire a new reading of the world" (pp. 15-16). 


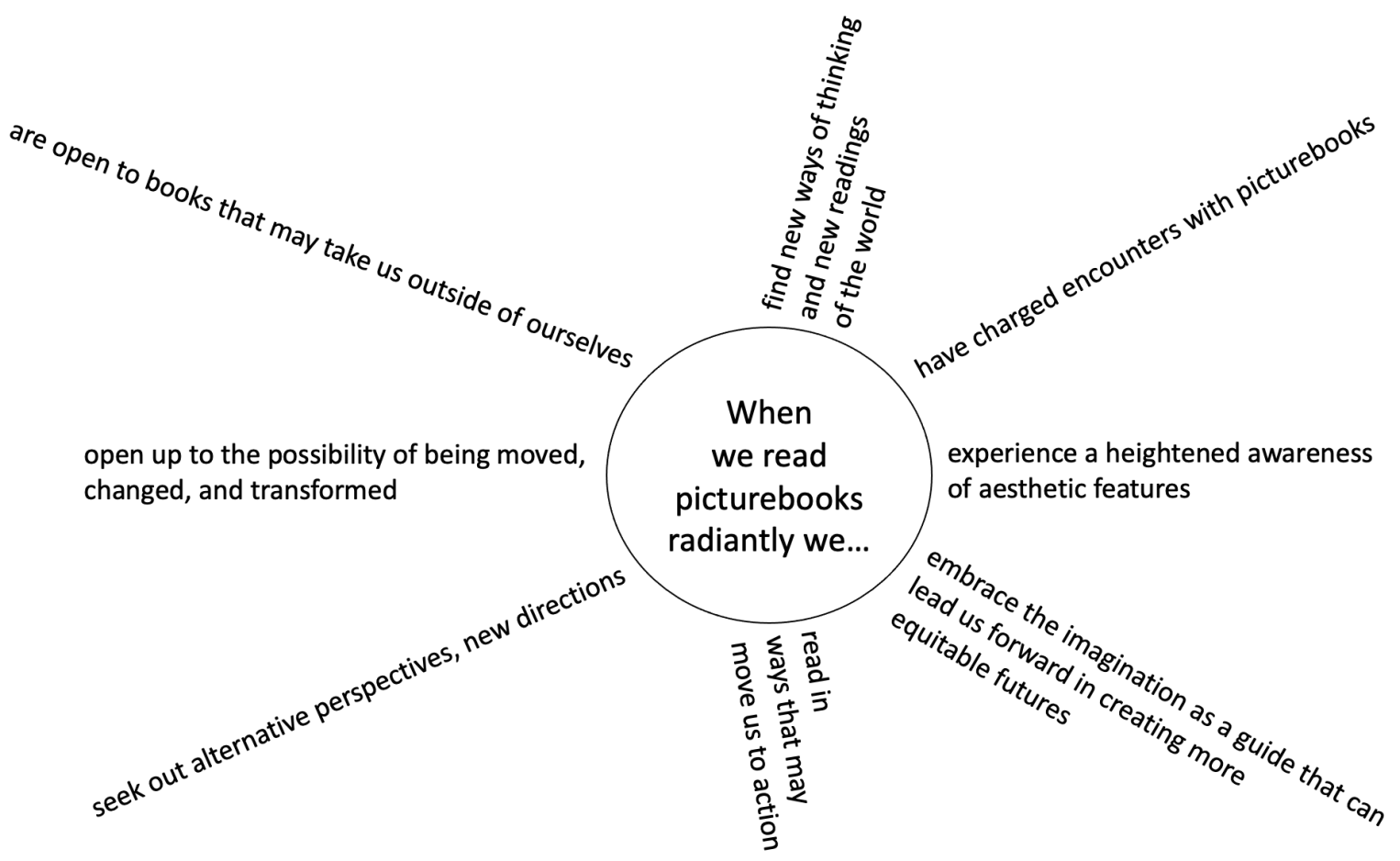

Figure 1. Radiant reading as openness and outward movement

Wissman suggests that picturebooks are ideal conduits for radiantly engaging children with the arts because they are aesthetic objects, in which both the visual and verbal sign systems interweave and contribute to meaning making. Engaging with the aesthetic aspects of picturebooks can thus lead us to what Kevin Tavin (2007) calls "a heightened awareness, radiance of mind, or a moving disposition we may have when engaging with art" (p. 41). Through collaborative inquiries with four elementary educators who incorporated diverse picturebooks with global themes into their teaching, Wissman observed that students engaged deeply with picturebooks, demonstrating this heightened awareness and radiance of mind, as they became "attuned to the text's aesthetic features: the poetics of the language, the beauty of a color, the movement of a line" (p. 15).

\section{Educators' Social Responsibility}

Short (2019) argues that socially responsible educators can enable socially responsible readers, mainly by creating educational contexts that encourage dialogic inquiry around global children's literature. Within these contexts "readers never read a book alone" (p. 7); meaning that they read books alongside other books and also read and discuss books along with other students. Emphasizing the danger of having 
students read a global book alone, Short explains that when her college students don't read a global book along with other books or materials, they tend to see that book as representative of an entire global culture. To avoid cultural misconceptions and stereotypical perceptions, she always asks students to read multiple texts, using intertextuality to create a context within which to read global children's literature: "When students read books alongside each other and within broader contexts, they are more likely to respond from a perspective of empathy, rather than sympathy" (p. 9).

Moreover, socially responsible educators have their students question why they have a particular response to a global story and think about how they are culturally

[...]socially responsible educators have their students question why they have a particular response to a global story and think about how they are culturally positioned in relation to the book's culture. Yet another strategy is to ask students to do some research, exploring the bookmakers' cultural locations in relation to the context of the book [...] positioned in relation to the book's culture. Yet another strategy is to ask students to do some research, exploring the bookmakers' cultural locations in relation to the context of the book, the term bookmakers including everyone who contributes to the publishing of a book, such as authors, illustrators, translators, and publishers (Short, 2019, p. 9). This might encourage students to think deeply about issues of cultural authenticity and representation.

An overarching social responsibility for educators is to create contexts that foster dialogue. Dialogue involves the openness mentioned earlier in this article, an openness that allows readers to listen and consider other students' interpretations that might differ from their own. It also involves an openness to engage difficult or even disturbing issues and thoroughly explore and discuss them, rather than merely identifying them at the surface level. Moreover, as dialogue combines critique and inquiry, we need to encourage readers to pose questions and challenge established ways of thinking and being (Short, 2019, p. 9).

Learning contexts that encourage students to engage in dialogue with each other and with diverse texts, characters, and cultures proved to be quite significant in Wissman's (2019) study on reading radiantly as well. She notably observed depth, complexity, and vibrancy in student discussions, when teachers engaged them in dialogic explorations of the picturebooks. Similarly, Short (2019) proposes dialogue strategies that encourage readers to reflect deeply on a book, consider multiple interpretations, and identify issues they consider important, rather than just discuss issues that the teacher has already identified. Such proposed strategies include Say Something, Save the Last Word for Me, Sketch to Stretch, Consensus Boards, and Webbing (Short \& Harste, 1996). 
I consistently use the dialogue strategies suggested by Short-mostly the first three-with my college students. Using the Say Something strategy, students work in pairs with one copy of the book between them. They take turns reading aloud from the book and stopping at a point they would like to say something. They repeat this process until they have read a pre-agreed section of the book. In Save the Last Word for Me, students discuss in groups of four. One of the group members selects an excerpt from the book and reads it to their group. The other three students then take turns speculating why the reader chose to share this specific excerpt with them. The reader remains silent but has the "last word" at the end to talk about their actual reason for selecting this excerpt. In Sketch to Stretch, students sketch the meaning(s) they make when reading a book and then share and discuss their sketches. I have found these strategies to effectively spark openness and outward movement, as they foster dialogue and encourage students to consider multiple perspectives that might differ from their own.

Most importantly, these strategies empower radiant readings and engage the social imagination, mainly because they nurture "reading as an act of creativity" (Wissman, 2019, p. 16); as a process that actively involves the reader's imagination. Wissman includes this quality in the main four features of instructional practice that supports the development of the social imagination and enables students to read radiantly (p. 16):

1. Selecting texts that broaden the imaginative landscape

2. Encouraging students to attend to the aesthetic attributes of picturebooks

3. Nurturing reading as an act of creativity

4. Creating space for agency and activism

Nurturing reading as an act of creativity entails supporting the students' aesthetic transactions and valuing knowledge created within the affective realm. Teachers who participated in Wissman's study, for example, used the following prompts to guide the discussion of a wide range of picturebooks that students read together in pairs:

1. What Really Matters to the Main Character

2. What Surprised Me or Worried Me about This Story

3. What I Still Wonder / Questions I Still Have (p. 20)

Wissman (2019) values these prompts as they do not ask children to merely reiterate facts or focus exclusively on comprehension; instead, they encourage young readers to consider interesting questions about people, life, and the human condition. And to answer these questions, students need to pay close attention to their sensory experiences and emotional responses to the texts and engage their social 
imagination. Wissman concludes that these prompts played an important role in students' success to read radiantly and to reflect deeply about the experiences of individuals across the world and across time.

I consistently use similar prompts with college students. Over the past few years, however, I have been finding that such prompts are most successful at engaging students with questions as the ones listed by Wissman, when they are posed in ways that spark students' creativity and imagination. Instead of directly asking what really matters to the main character, for instance, I may ask students to imagine what the protagonist would take with them if they had to leave their home permanently; or I may pause during a read-aloud and ask them to speak as if they are the main character's consciousness; or I may

[...] instead of directly asking the question of what surprised or worried them, I may ask them to post emojis that reflect how they felt at different points in the story, and rather than asking what they are still wondering about, I may ask them to do "annotated spreads" have them conduct an imagined interview with the protagonist (as I did in one of the activities described in the following section). Similarly, instead of directly asking the question of what surprised or worried them, I may ask them to post emojis that reflect how they felt at different points in the story, and rather than asking what they are still wondering about, I may ask them to do "annotated spreads" (as described by Farrell, Arizpe, and McAdam, 2010) which can involve selecting an image from the picturebook and annotating it with looming questions.

\section{Engaging the Social Imagination in the College Classroom}

Nurturing reading as an act of creativity and fostering dialogic inquiry around global picturebooks has been quite effective in engaging college students' social imagination. In this section, I bring evidence that supports this effectiveness from one of my classes, demonstrating the different ways in which students were able to read two global picturebooks radiantly. This was an online class I taught at the University of Georgia in the fall of 2020. The course surveys diverse children's literature and is open to students from all across the campus. Twenty-six students were enrolled in this class, most of them in their second year of studies and about half of them being education majors. The other half came from departments across the University. The students had diverse cultural backgrounds but more than half of them were white female students. While it would be useful to look more closely at the students' backgrounds and investigate how these corelated with their responses to the picturebooks, for the purposes of this study I take a wider-angle approach, looking at two artifacts they created-one for each picturebook-and analyzing them to see if and how the students read radiantly. 
Taking Kathy Short's advice to never read a book alone, I chose to have students read together two very

In addition to the urgency of the social issues present in these picturebooks and my personal identity and experiences as an immigrant, I also gravitated towards these specific stories because research has shown that reading about migration and refugee experiences can raise the level of awareness, vicarious engagement, and empathy in students different picturebooks that share the common theme of immigration. In addition to the urgency of the social issues present in these picturebooks and my personal identity and experiences as an immigrant, I also gravitated towards these specific stories because research has shown that reading about migration and refugee experiences can raise the level of awareness, vicarious engagement, and empathy in students (Arizpe, et alii, 2014; Hope, 2017; Lysaker \& Sedberry, 2015). Other research has found that when reading such picturebooks, refugee and migrant students feel that their experiences are validated and that they are not alone in confronting issues related to displacement (Arizpe,

Colomer, \& Martínez-Roldán, 2014).

The first picturebook was Two White Rabbits (2015), authored by Jairo Buitrago, translated by Elisa Amado, and illustrated by Rafael Yockteng. It was first published in Canada and is set in Mexico. A young girl is the narrator of this moving story, sharing her feelings, thoughts, and experiences as she and her father make the arduous journey toward the US border. The second one was the wordless picturebook The Arrival (2007) by Shaun Tan, which was first published in Australia and takes place in a fantasy world. It tells the story of a father who migrates to a distant and unfamiliar country to build a better future for his family, starting with the painful separation from his family and progressing to his long journey, his arrival at the foreign land, the hardships and isolation he faces there, the connections he begins to make, and the reunification with his family. Both picturebooks are stunningly illustrated, inviting readers to attend to their aesthetic attributes in the ways that Wissman suggests.

\section{Radiant Readings of Two White Rabbits}

In Two White Rabbits, the illustrations imply that the father's perspective is different from that of the girl, who is narrating the story. This perspective difference is evident even in the cover image, where the two main characters travel on the roof of a train and feature contrasting gazes and facial expressions. 


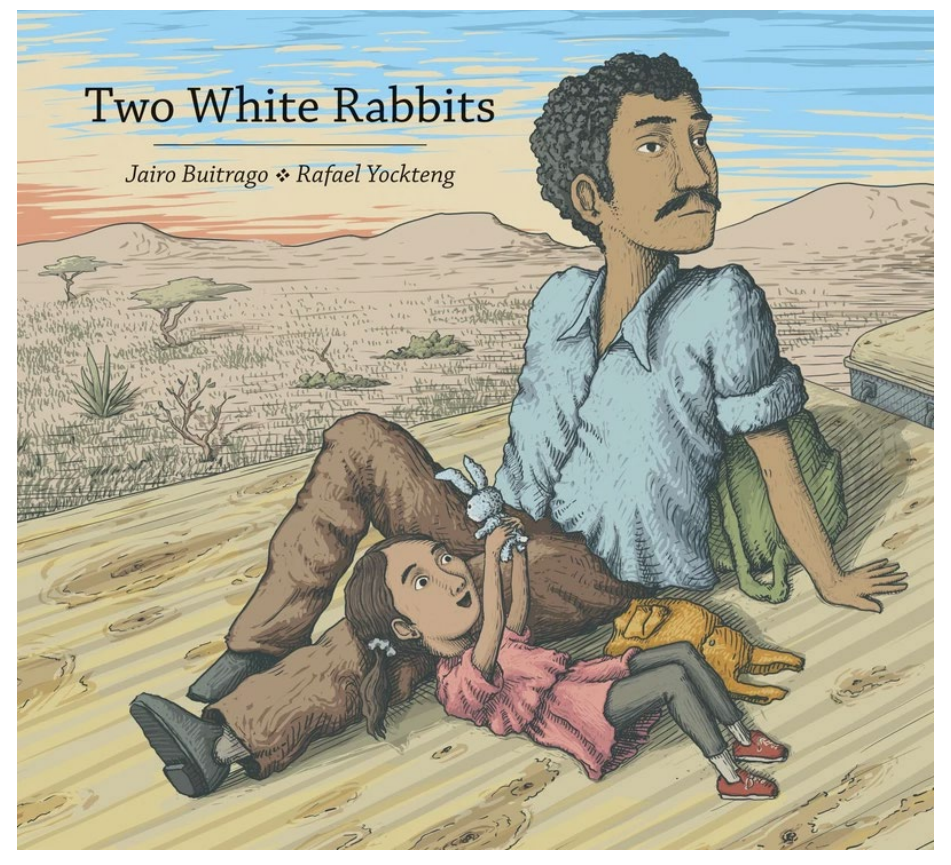

Figure 2. Perspective difference in the cover image of Two White Rabbits

Students responded to a prompt that asked them to zero in on this contrast of perspectives. Taking Wissman's advice to create prompts that cultivate the social imagination, pose questions about readers, people, and the human condition, and invite students to pay attention to their sensory experiences and emotional responses, I designed the following prompt:

- Retell the story from Dad's Perspective

- Read the picturebook Two White Rabbits. Write at least one sentence for most of the images (usually double-spreads) in the book, re-telling the story through the eyes of dad.

- After you have posted your own entry, respond to at least two other posts, comparing and contrasting the different ways in which different people have responded to this assignment. What do you observe?

Students' responses overwhelmingly demonstrated their radiant readings of the story, and the discussion that followed-as encouraged by the second part of the prompt-showed an openness to consider multiple perspectives that might differ from their own. 
In variable degrees, students showed heightened awareness of the picturebook's aesthetic features. They paid close attention to such visual elements such as color, line, placement on the page, facial expressions, and body language and this enabled them to imagine the father's thoughts and emotions in spite of the fact that these are not verbalized in the girl's narration. In the first two double spreads, for instance, the girl only says the simple phrase "When we travel, I count what I see." For the same four pages, a student provided the following alternate narration with the father as narrator:

When we travel, she sits on my shoulders and holds on tight.

Though my legs get tired, my heart warms at the sound of my smart young hija counting aloud all the animals she sees. She doesn't know what is to come, and her enthusiasm encourages me on our journey.

The student's use of the Spanish word "hija" emphasizes the father's affection for his daughter. Paying attention to the visual aesthetics, the student is also able to imagine and put the father's sensory experiences into words ("my legs get tired") as well as his emotional responses ("my heart warms at the sound..."). She even captures such complex sentiments such as apprehension ("She doesn't know what is to come") and hope ("her enthusiasm encourages me on our journey"). The same student later writes "I try to stay calm for her sake, but I am scared," demonstrating how she let the book take her outside of herself to empathize and experience the story through the father's eyes.

The visual storytelling in Two White Rabbits is evocative but aspects that diverge from the textual storytelling are also open to multiple interpretations. This is true for a page that reads "Where are we going?' I sometimes ask but no one answers." The student quoted above wrote the following from the father's perspective:

"Where are we going?" she asks me. I do not answer her. Instead, we just walk on. I cannot tell her where we go. I cannot tell anyone, but we must keep going.

Two other students, on the other hand, wrote the following:

"Where are we going". I softly hear her ask, but I couldn't focus on her as my mind was somewhere else. I was making sure the men with guns didn't see us.

Sometimes she asks me where we are going. It's too much for her to understand; I say nothing. 
The first student imagines that the father cannot tell anyone where they are going because that would put them in danger. The second student imagines that he doesn't say anything because he is preoccupied with avoiding the men with guns. And the third student imagines that he thinks his girl is too young to understand. While the three students fill in the gaps in very different ways, they do so imaginatively, demonstrating that their social imagination - their capacity "to extrapolate beyond what is presented in the text to imagine the thoughts, feelings, and experiences of others" (Wissman, 2019, p. 15)-has been energized.

The students' diverse interpretations are most obvious in relation to the last, wordless, double spread in the picturebook. Here, the father is shown to release the two white rabbits that accompanied them as pets for part of their journey into a wild landscape that is disrupted by the presence of a huge border wall. As shown in table 1, while some students followed the original narration and did not add any text under the image, several offered their interpretations of the father's gesture.

\begin{tabular}{|c|c|}
\hline Student 1 & $\begin{array}{l}\text { Our trip must continue, but the rabbits cannot come. I can't manage food for them } \\
\text { on this journey, too... }\end{array}$ \\
\hline Student 2 & $\begin{array}{l}\text { As the bunnies hop away, they lead the way to the border we have been seeking, } \\
\text { and we have finally made it. }\end{array}$ \\
\hline Student 3 & $\begin{array}{l}\text { Once we are there we set the two rabbits free. They are now free just like you and } \\
\text { me. }\end{array}$ \\
\hline Student 4 & $\begin{array}{l}\text { When we get off the truck, I let the rabbits go. They should get to experience the } \\
\text { freedom that I so desperately want for her. }\end{array}$ \\
\hline Student 5 & In the middle of a desert, we let them go. Free. And they run straight to the border. \\
\hline Student 6 & $\begin{array}{l}\text { I set the two rabbits free as they should be. Now, the only thing stopping me and } \\
\text { her from freedom is the wall. }\end{array}$ \\
\hline
\end{tabular}

Table 1. Diverse interpretations of the father's gesture to release the rabbits

Different students "read" this final image in pragmatic or symbolic ways, and where some see hope others see hopelessness or frustration. In any case, both types of responses, as well as the sharing and discussion that followed, showed that:

- Students had a charged encounter with the picturebook (the poetic language they used in their responses highlights this) 
- They sought out alternative perspectives and new directions (they successfully completed an assignment that asked them to do just that)

- And were open to new ways of thinking, new readings of the world (their discussion was peppered with comments that acknowledged how their peers' posts made them see things differently).

\section{Radiant Readings of The Arrival}

Similarly, the students' responses to The Arrival demonstrated heightened awareness of the aesthetics, charged encounters with the picturebook, and openness to new ways of reading the world. Interestingly enough, these manifestations of the social imagination were most evident in the questions the students asked. Unlike the Two White Rabbits cover image, The Arrival cover features eye-contact between two characters; this does not reassure the reader, however, as we notice that the human character is alarmed and perplexed by this encounter with a strange creature (Figure 3 ).

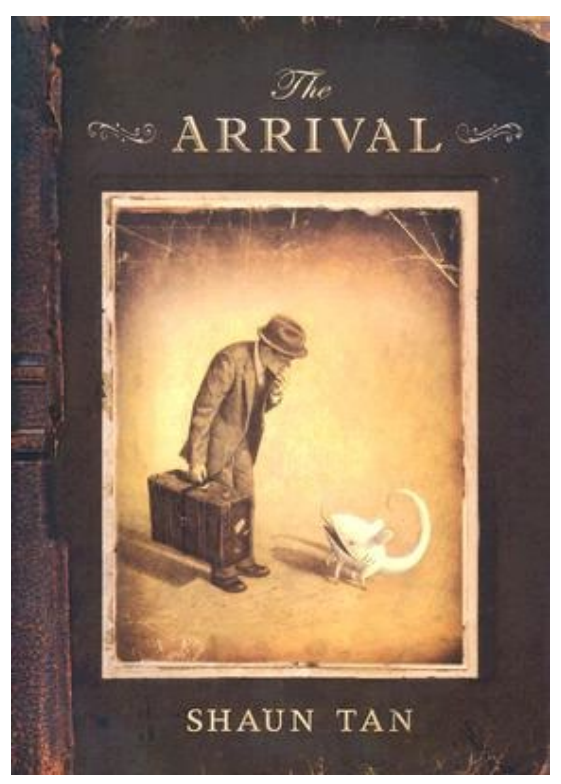

Figure 3. Eye-contact between two characters in The Arrival cover image

By creating an entire imaginary place, culture, and language that are foreign to all readers and creating a wordless picturebook around a character who is "wordless" himself in the new place he immigrates to, Shaun Tan invites readers to empathize with the protagonist's fears, struggles, and frustrations. This is why I thought inviting students to let the main character's voice be heard was a fitting assignment, and one that also fitted Wissman's call for prompts that cultivate the social imagination: 


\section{Interview the main character}

Read/View the wordless picturebook The Arrival. Then write an imagined interview with the main character in the book. Ask him at least five questions and write how you imagine him answering them.

After you have posted your own entry, respond to at least two other posts, comparing and contrasting the different ways in which different people have responded to this assignment. What do you observe?

As shown in the table below (Table 2) students asked pragmatic questions as well as questions from an affective realm. Some focused more on one of the two categories of questions, while others kept a balance between the two.

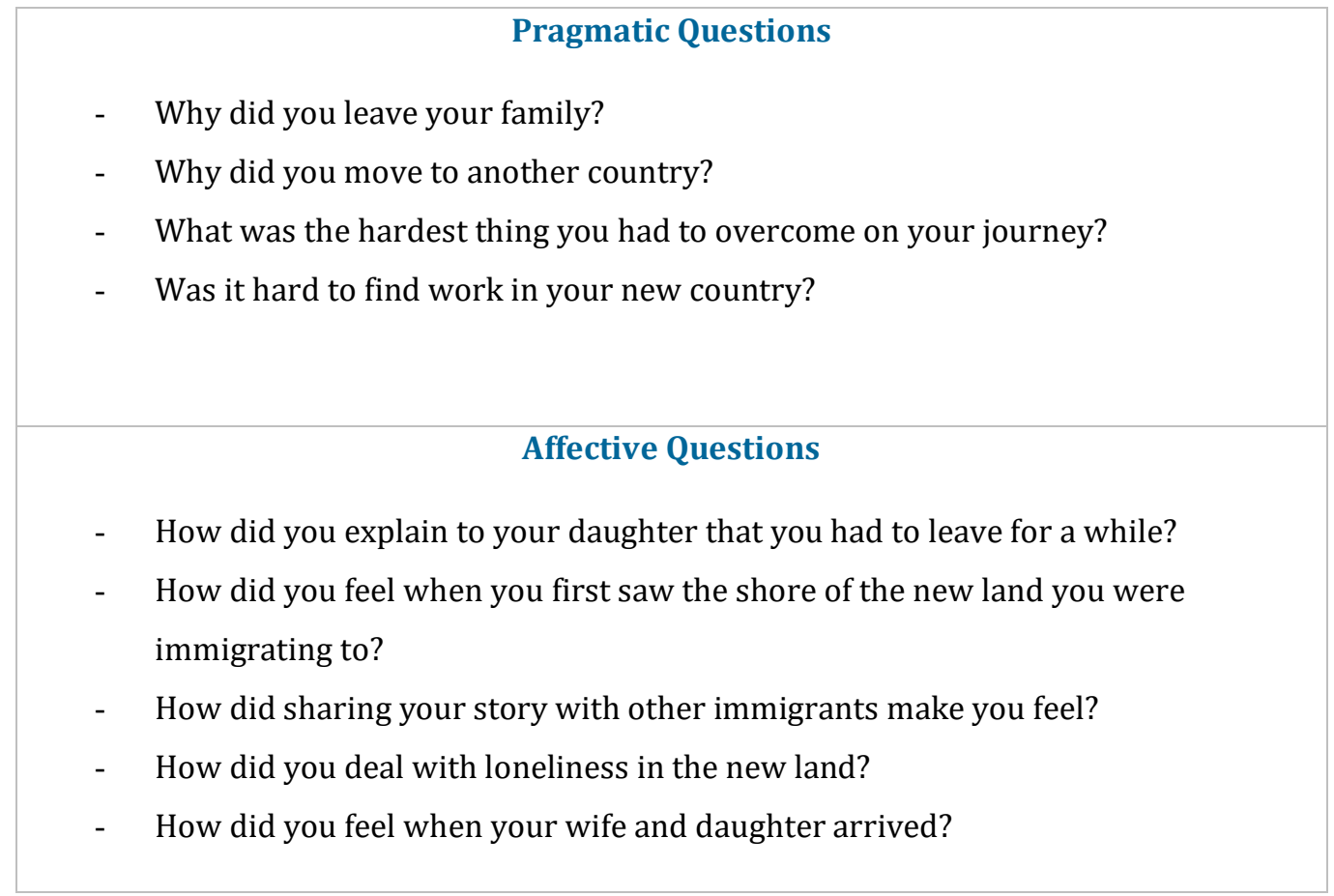

Table 2. Pragmatic and affective questions in student interviews

Regardless of the category they fall under, though, these questions show the students' effort to see the world through the eyes of a different person and a conscious openness to a book that may take them outside of themselves.

Because The Arrival is wordless, and as Tan loves to use symbolism in his illustrations, there was plenty of room for multiple interpretations. One instance with noticeably diverse interpretations was students' 
speculation about why the main character had to leave his family and migrate to a faraway place. The only explanation Tan provides is an image of the protagonist's homeland under the shadow of a giant, spiky, reptile-like monster. While the majority of the students imagined the main character as an economic migrant (similar to the US mainstream image of the immigrant), some students imagined him to be a refugee or an asylum seeker:

The sharing and discussion demonstrated that most students were open to other interpretations, new ways of thinking, new readings of the world. They paid attention to the second part of the prompt that encouraged them to compare and contrast the different ways in which different people responded to the assignment. They were even open to revisiting and revising their initial interpretations, allowing themselves to be influenced by other people's responses to this visual narrative.

Imagining the main character as an economic migrant
- $\quad$ My hometown was an impoverished town. We could no longer have a life
there.
- $\quad$ I wanted a better life for myself and my family.
Imagining the main character as a refugee or an asylum seeker
- $\quad$ My old country was plagued with a monster within. The government was
turning on its people.
- My home country was becoming a dangerous place for my family. I wanted
to escape from there and get my family to safety.

Figure 4. Imagining the main character as an economic migrant or a refugee/asylum seeker

The sharing and discussion demonstrated that most students were open to other interpretations, new ways of thinking, new readings of the world. They paid attention to the second part of the prompt that encouraged them to compare and contrast the different ways in which different people responded to the assignment. They were even open to revisiting and revising their initial interpretations, allowing themselves to be influenced by other people's responses to this visual narrative.

As with the Two White Rabbits picturebook, students' responses and the sharing and discussion that followed showed that they had a charged encounter with The Arrival. The powerfully poetic language some students used is indicative:

Interviewer: How did you feel about this new land?

Interviewee: It was terrifying and beautiful. It was strange yet wonderful. 
Interviewer: Is there anything you learned as an immigrant that you would pass down to your children?

Interviewee: We only survive because of each other. Take care of that community, no matter how different, big, or small, because only when you take care of the people around you, do you take care of yourself.

\section{Discussion}

The prompts, which were designed for two different picturebooks themed around immigration, were successful in nurturing reading as an act of creativity and fostering dialogic inquiry; and thus, also succeeded in engaging the students' social imagination. A main reason behind their success was that, by design, they required readers to use their imagination and creativity, and pay close attention to the picturebooks' visual aesthetics to fill in the gaps. This was also facilitated by my ascribing to Arizpe's (2021) advice to "allow students plenty of time for both 'slow looking' and 'deep thinking' and introduce visual literacy terms so they can talk about what they observe" (p. 268).

Another important reason behind the students' successful radiant readings was the selection of these specific picturebooks. Short (2019) suggests that socially responsible readers "remain open to books that depict cultural ways of living that are unfamiliar and so may cause discomfort" (p. 5). And Jessica Whitelaw (2017) considers that this embracing of unfamiliarity and discomfort is encouraged by certain kinds of

Furthermore, both picturebooks invite readers to empathize with the characters as they hurt and go through traumatic experiences, and students' empathetic responses are evident in their artifacts. Both picturebooks also invite close looking and offer the reader/viewer moments of pause and reflection, an affordance that the students relied heavily upon in order to imagine the characters' thoughts and feelings. stories, which she calls disquieting picturebooks. She identifies five different kinds of disquieting: embracing ambiguity; opening to hurt; pausing for interruption; hearing silences; and witnessing resistance.

Two White Rabbits and The Arrival feature four of these five kinds of disquieting. The ambiguity in both stories (especially evoked through the illustrations) caused diverse interpretations amongst students. Furthermore, both picturebooks invite readers to empathize with the characters as they hurt and go through traumatic experiences, and students' empathetic responses are evident in their artifacts. Both picturebooks also invite close looking and offer the reader/viewer moments of pause and reflection, an affordance that the students relied heavily upon in order to imagine the characters' thoughts and feelings. The fourth kind of disquieting, 
hearing silences, is also evident as both stories bring silenced/marginalized stories to the fore; students listened attentively to the silenced characters and imagined what they would say having been empowered to do so. Witnessing resistance is the only disquieting feature in the two picturebooks that is not as powerfully present as the others.

The lack of this last feature can partly explain why some aspects recognized by Wissman as major attributes of reading radiantly were not fully realized. As resistance was not foregrounded in the picturebooks, students did not seem inspired to take action and resist social establishments that oppress the main characters' real-life counterparts. Having created a "Radiant Reading Checklist" I would check the first five elements as strongly present in the student artifacts, whereas the last three-and especially the last one: "reading in ways that may move us to action" - were not fully realized (Figure 5).

- be open to books that may take us outside of ourselves (C)

- seek out alternative perspectives, new directions (C)

- new ways of thinking - new readings of the world (C)

- have a charged encounter with a picturebook (C)

- heightened awareness of its aesthetic features (C)

- embrace the imagination as a guide that can lead us forward in creating more equitable futures

- be open to the possibility of being moved, changed, and transformed

- read in ways that may move us to action

Figure 5. Radiant Reading Checklist

I recognize the importance of the last three items on this list and the valuable effects they can have both for individual students and for social change. As Op de Beeck (2017) observes in relation to picturebooks about the environment, critical praxis is needed if sociopolitical practices are to be changed (p. 124). For students to be moved to action, though, they need to be able to imagine themselves as people with agency; people that can bring about social change. Writing about school-age readers, several scholars have argued that engaging students with stories that feature characters who take action for social change can inspire them to also envision themselves as agents of social change (Kornfeld \& Prothro, 2005; Mathis, 2017; Short, 2012). Janelle Mathis (2017) argues that "experiencing acts of agency through reading authentic international children's literature offers powerful ways to learn about other members of the global community as well as consider the potential for one's own agency" (p. 220). I believe the same 
applies for college-level readers' interaction with such literature. This is why in future reiterations of my children's literature class I plan to also include picturebooks that more explicitly enable students to witness and envision agency and resistance.

Moreover, I recognize that the goals of enabling students to be transformed and moved to action for social change cannot be fully achieved merely through interactions around well-designed prompts, such as the ones I have described. Students need to be given the time and space for critical inquiry, so they can explore and identify the local and/or global issues that they consider important and worthy of their effort and intervention; as well as relevant venues of action. Thus, in the future I will more intentionally design into my curriculum Wissman's (2019) fourth feature of effective instructional practice, namely creating space for agency and activism.

\section{Conclusion}

Nurturing reading as an act of creativity and fostering dialogic inquiry around global picturebooks has been shown to be quite effective in engaging college students' social imagination. I brought evidence from the prompts I designed and the artifacts that students produced in response to these prompts that supports this effectiveness, demonstrating the different ways in which students were able to read Two White Rabbits and The Arrival radiantly.

Students' responses overwhelmingly demonstrated their radiant readings of the stories, and their discussions showed an openness to consider multiple perspectives that might differ from their own. In variable degrees, students showed heightened awareness of the picturebooks' aesthetic features, had charged encounters with the picturebooks, and demonstrated openness to new ways of reading the world. They paid close attention to such visual elements such as color, line, placement on the page, facial expressions, and body language and this enabled them to imagine the characters' thoughts and emotions. The manifestations of students' social imagination were often evident in the questions they asked. Their sharing and discussions demonstrated that most students remained open to other interpretations, new ways of thinking, and new readings of the world. Paying attention to the second part of the prompts that encouraged them to compare and contrast the different ways in which different people responded to the assignment, they were open to revisiting and revising their initial interpretations.

The prompts succeeded in engaging the students' social imagination because they were designed based on Wissman's advice to create prompts that pose questions about readers, people, and the human condition, and invite students to pay attention to their sensory experiences and emotional responses. 
Additionally, they were designed to nurture reading as an act of creativity and to foster dialogic inquiry. By design, the prompts required readers to use their imagination and creativity, as well as pay close attention to the picturebooks' visual aesthetics. Another important reason behind the students' successful radiant readings was the selection of these specific picturebooks, which both follow Short's (2019) principle to never read a book alone and fit Whitelaw's (2017) definition of disquieting picturebooks; picturebooks that encourage the embracing of unfamiliarity and discomfort.

Nevertheless, witnessing resistance, one of the main features of disquieting picturebooks was not as powerfully present in the two picturebooks as the other features listed by Whitelaw. The absence of this feature can partly explain why some of the major attributes of reading radiantly were not fully realized. As resistance was not foregrounded in the picturebooks, students were not inspired to take action and resist the status quo that oppresses the main characters' real-life counterparts. In future reiterations of my children's literature As resistance was not foregrounded in the picturebooks, students were not inspired to take action and resist the status quo that oppresses the main characters' real-life counterparts class, I will adjust my instruction to create more space for agency and activism, and strive to include picturebooks that more explicitly enable students to witness and envision agency and resistance.

As a socially responsible educator, I need to continue using approaches that enable students to read radiantly and further explore more holistic approaches of engaging students' social imagination, which can encourage them to be transformed and moved to social action. And as a socially responsible researcher, I also need to further study the potential and potency of reading global picturebooks radiantly to engage the social imagination in the college classroom.

\section{References}

Arizpe, E. (2021). The state of the art in picturebook research from 2010 to 2020. Language Arts 98(5), $260-272$.

Arizpe, E., Bagelman, C., Devlin, A. M, Farrell, M., \& McAdam, J. E. (2014). Visualizing intercultural literacy: Engaging critically with diversity and migration in the classroom through an image-based approach. Language and Intercultural Communication 14(3), 304-321.

Arizpe, E., Colomer, T., \& Martínez-Roldán, C. (2014). Visual journeys through wordless narratives: An international inquiry with immigrant children and The arrival. Bloomsbury Academic.

Buitrago, J., \& Yockteng, R. (Illustrator). (2015). Two white rabbits. Groundwood Books. 
Hope, J. (2017). Children's literature about refugees: A catalyst in the classroom. Trentham.

Ellis, D. (2019). Before they give the order: A 2018 IBBY keynote speech. Bookbird: A Journal of International Children's Literature 57(1), 1-13.

Enciso, P. (2017). Stories lost and found: Mobilizing imagination in literacy research and practice. Literacy Research: Theory, Method, and Practice 66, 29-52.

Farrell, M., Arizpe, E., \& McAdam, J. (2010). Journeys across visual borders: Annotated spreads of The Arrival by Shaun Tan as a method for understanding pupils' creation of meaning through visual images. Australian Journal of Language and Literacy 33(3), 198-210.

Green, M. (1995). Releasing the imagination: Essays on education, the arts, and social change. Jossey Bass.

Kornfeld, J., \& Prothro, L. (2005). Envisioning possibility: Schooling and student agency in children's and young adult literature. Children's Literature in Education 36(3), 217-239.

Lysaker, J., \& Sedberry, T. (2015). Reading difference: Picture book retellings as contexts for exploring personal meanings of race and culture. Literacy 49(2), 105-11.

Op de Beeck, N. (2017). Environmental picturebooks: Cultivating conversations. In P. Nodelman, N. Hamer, \& M. Reimer (Eds.), More words about pictures (pp. 116-26). Routledge.

Short, K.G., \& Harste, J. (1996). Creating classrooms for authors and inquirers. Stenhouse.

Short, K.G. (2012). Children's agency for taking action. Bookbird: A Journal of International Children's Literature 50(4), 41-50.

Short, K.G. (2019). The dangers of reading globally. Bookbird: A Journal of International Children's Literature 57(2), 1-11.

Tan, S. (2007). The arrival. Lothian Books.

Tavin, K. (2007). Eyes wide shut: The use and uselessness of the discourse of aesthetics in art education. Art Education 60(2), 40-45.

Whitelaw, J. (2017). Beyond the bedtime story: In search of epistemic possibilities and the innovative potential of disquieting picturebooks. Bookbird: A Journal of International Children's Literature 55(1), 33-41.

Wissman, K.K. (2019). Reading radiantly: Embracing the power of picturebooks to cultivate the social imagination. Bookbird: A Journal of International Children's Literature 57(1), 14-25.

\section{How to cite this paper:}

Panaou, P. (2021). Engaging the Social Imagination in the College Classroom Through Radiant Readings of Global Picturebooks. Journal of Literary Education, (4), 154-173. https://doi.org/10.7203/JLE.4.21027 